\title{
A peleja da Música Armorial: o maestro contra o escritor
}

\author{
Luan Glauco Freire Costa* \\ lvanglauco@hotmail.com
}

\begin{abstract}
Resumo
O presente artigo discorre acerca dos conflitos na constituição erudita das obras da música armorial. O Movimento Armorial surgiu na cidade do Recife, no ano de 1970, sobre a orientação do escritor e teatrólogo Ariano Suassuna. Sendo historicamente influenciado pelo Movimento Regionalista e Escola de Pernambuco, resgatando o contexto da música erudita brasileira do séc. XX, moldada pelas figuras de Villa-Lobos e Mário de Andrade como principais idealizadores da música erudita nacional. A música armorial foi constituída por grandes compositores nacionais que versavam sobre temas regionais como Guerra Peixe e Capiba. A peleja tomará lugar a partir dos conflitos agravados entre o escritor Ariano Suassuna e o Maestro Cussy de Almeida, tendo seus ideais estéticos representados pelo Quinteto Armorial e pela Orquestra Armorial, respectivamente. A análise do conflito na constituição das regras e normas artísticas e criativas na formação das obras resultará na leitura do campo simbólico constituinte da esfera erudita da música do movimento armorial e o lugar histórico ocupado por cada figura aqui apresentada na construção da música erudita nordestina.
\end{abstract}

\section{Palavras-Chave}

Música armorial; Popular; Erudito

\section{The Fight of Armorial Music: The conductor against the writer}

\begin{abstract}
This article discusses the conflicts in the erudite constitution of works of armorial music. The Armorial Movement arose in the city of Recife, in the year of 1970, on the orientation of the writer and theatrólogo Ariano Suassuna. Being historically influenced by the Regionalist Movement and School of Pernambuco, rescuing the context of the erudite Brazilian music of the century. $X X$, shaped by the figures of Villa-Lobos and Mário de Andrade as main idealizers of the national scholarly music. Armorial music was composed of great national composers who dealt with regional themes like Guerra Peixe and Capiba. The battle will take place from the aggravated conflicts between the writer Ariano Suassuna and the Conductor Cussy de Almeida, having its aesthetic ideals represented by the Armorial Quintet and the Armorial Orchestra respectively. The analysis of the conflict in the constitution of the rules and artistic and creative norms in the formation of the works will result in the reading of the symbolic field constituent of the erudite sphere of the music of the armorial movement and the historical place occupied by each figure presented here in the construction of erudite northeastern music.
\end{abstract}

Keywords

Armorial music; Pop; Erudite 


\section{Introdução}

Foi em uma noite de domingo, em uma Igreja situada no centro do Recife, com balaústres e adornos em cantaria e dedicada à São Pedro dos Clérigos que, em de 18 de setembro de 1970, ecoavam para o público os acordes armoriais. Sobre o Signo Armorial, reuniram -se grupos de artistas e intelectuais impulsionados pela imaginação criativa e ideais do escritor e teatrólogo Ariano Suassuna, mentor do movimento. Com o desejo de criar uma arte erudita autenticamente brasileira fundada nas raízes populares, os artistas armoriais lançaram-se em suas pesquisas acerca das culturas populares para transmutar o ímpeto criativo destes em estruturas eruditas. O Jornal Diário de Pernambuco, em artigo denominado "Novo movimento musical surgirá hoje no Recife", registrou o lançamento do movimento:

"Três séculos de música Nordestina: Do Barroco ao Armorial". É a denominação de um novo movimento artístico-musical que será lançado hoje, às 21 horas, em concerto, na Igreja de São Pedro dos Clérigos, constando de duas partes: a primeira, oferecerá músicas nordestinas do séc. XVIII, com dois compositores: José Lima e Luís Alvares Pinto; a segunda, compreenderá a apresentação de música nordestina do séc. XX, música erudita de Capiba, Guerra Peixe, Jarbas Maciel, Clóvis Pereira e Cussy de Almei$d a$

Paralelamente será instalada uma exposição de talhas, desenhos, gravuras e pinturas, de artistas como Brennand, Fernando Torres Barbosa, Fernando Lopes da Paz, Manuel Arruda e Gilvan Samico. Haverá, também, exposição de livros de poetas e escritores, como Maximiano Campos, Janice Japiassu, Ângelo Monteiro, Marcus Accioly, Deborah Brennand e Ariano Suassuna. Caberá ao escritor Ariano Suassuna pronunciar, na oportunidade, uma palestra, com exibição de "slides" sobre a experiência que vem sendo feita no Departamento de Extensão Cultural da Universidade Federal de Pernambuco, dentro do seminário permanente de Música e Arte Nordestina. (Diário de Pernambuco, Recife, 18 de setembro de 1970, p.32).
Esta pequena anunciação permite compreender características específicas que o movimento apresentava já em seu lançamento. Em primeiro lugar: a Música ocupava lugar central nos trabalhos exercidos pelos armoriais. É possível perceber isso pelo título atribuído ao artigo que define um novo movimento musical e não um novo movimento artístico. O Armorial englobava outras esferas de produção artística, como o próprio artigo vem a ressaltar ao elucidar a exposição de artes plásticas e os trabalhos literários que também estariam presentes, mas a Música Armorial já estava situada em lugar de maior relevância dentre estas. O artigo também permite evidenciar a grande quantidade de artistas e intelectuais que acompanhavam o escritor Ariano $\mathrm{Su}$ assuna em sua empreitada. Nomes como Capiba, Guerra Peixe, Francisco Brennand, Maximiano Campos, Marcus Accioly e Gilvan Samico, artistas e intelectuais que até hoje ocupam grande espaço na memória e imaginário artístico do Brasil já estavam presentes e envolvidos com o movimento desde o seu lançamento oficial. Além disso, o artigo deixa claro também que o Armorial não surge apenas de uma inspiração artística, mas que, pelo contrário, já vinha sendo trabalhado anteriormente com as pesquisas exercidas no meio acadêmico através do Departamento Extensão Cultural da Universidade Federal de Pernambuco do qual Ariano Suassuna era diretor (SANTOS, 1999, p. 21). A elite intelectual e artística que acompanhava Suassuna em sua nova empreitada buscava soerguer o discurso regionalista fundado por Gilberto Freyre em 1926 como um meio de revalidar e reassegurar seus poderes sociais, pois "um intelectual regionalista quase sempre é aquele que se sente longe do centro irradiador de poder e de cultura. Ele faz denúncia dessa distância, dessa carência de poder, dessa vitimização, o motivo de seu discurso" (ALBUQUERQUE, 1999, p.50). Para os armoriais, o Nordeste, tal qual professado por Gilberto Freyre (FREYRE, 1996), surge como lugar inequívoco das 
verdadeiras riquezas da tradição Brasileira e, consequentemente, da história nacional. Era o discurso performativo $^{1}$ acerca das características do que era "autenticamente" Nordestino que garantiu a ascensão do poder simbólico, político e cultural de Ariano Suassuna e seus seguidores.

Ainda enfatizando o lugar central ocupado pela música, o artigo dedica um espaço de sua coluna para referenciar os trabalhos anteriores da Orquestra de Câmara Armorial e o concerto realizado naquela noite de Domingo.

O concerto será levado a efeito pela Orquestra de Câmara Armorial de Pernambuco. As músicas do séc. XX foram compostas especialmente para o Departamento de Extensão Cultural da UFP, no decorrer dos estudos realizados pelo Seminário Permanente de Arte Nordestina, por um grupo de compositores conhecidos internacionalmente.

O professor Ariano Suassuna, coordenador desses trabalhos, declarou que esse movimento representa um trabalho de preparação do público jovem para a música erudita. Apresenta músicas eruditas europeias e músicas eruditas brasileira. (Diário de Pernambuco, Recife, 18 de setembro de 1970. P.32).

Mas o que significava “Armorial”? Palavra sonora, mas ainda tão estranha à realidade de um movimento artístico que começava a constituir-se naquela noite. Ninguém melhor do que Ariano Suassuna para definir aquilo que imaginava então no lançamento do movimento. Em entrevista publicada no mesmo artigo o escritor afirmava:

Muitas tem sido as pessoas que, estranhando o nome da orquestra e esse qualitativo de "armorial" que estamos empregando para a nossa Música, me perguntam o que significa isso. Respondo: em nossa língua Portuguesa, "armorial" é apenas substantivo. Passei a empregalo também como adjetivo. Primeiro, porque é um belo nome. Depois, porque é ligado aos esmaltes da Heráldica, limpos, nítidos, pintados sobre metal ou, por outro lado, esculpidos em pedra, com animais fabulosos cercados por folhagens, sóis, luas e estrelas.

Ora, nas minhas conversas com meus amigos, comecei a sentir falta de um qualitativo para determinadas formas de Arte nordestina e brasileira que procurávamos e procuramos. Foi ai que, meio sério, meio brincando, comecei a dizer que tal poema ou qual estandarte de Cavalhada ou Maracatu era "armorial", isto é, brilhava em esmaltes puros, festivos, nítidos, metálicos e coloridos, como uma bandeira, um brasão ou um toque de clarim. De fato, a Heráldica é a arte dos selos, dos escudos e das bandeiras, das insignias. Lembrei-me, ai, também, das pedras armoriais dos portões e frontadas do Barroco brasileiro, e passei a usar o nome também para as esculturas que sonhava para o Nordeste. Descobri, ainda, que o nome "armorial" servia também para qualificar os cantares do Romanceiro, para os toques de rabeca e viola dos Cantadores - toques ásperos e arcaicos, acerados como gumes de facade-ponta, lembrando o clavicórdio e a viola de arco de nossa Música barroca do século XVIII. E assim, aos poucos, terminei por estender o nome "armorial" ao Cinema, à Gravura, à Escultura, ao Teatro, ao Romance, à Pintura, à Poesia, enfim, a todas as manifestações de Arte com as quais eu sonhava para o Sertão, para a Zona da Mata, para o Nordeste, para o Brasil, para a América Latina. (Diário de Pernambuco, Recife, 18 de setembro. 1970, p.32).

A alcunha Armorial surge, em primeiro lugar, pela beleza sonora da enunciação de seu nome, em segundo, pelas concepções e imagens do escritor em relação as artes Nordestina e Brasileira. Surge da necessidade em definir aquilo que o teatrólogo idealizava nas conversas com seus amigos e abarcava, em um todo, as

\footnotetext{
1“'O discurso regionalista é um discurso perfomativo, que tem em vista impor como legítima uma nova definição das fronteiras e dar a conhecer e fazer reconhecer a região assim delimitada [...] A eficácia do discurso performativo que pretende fazer sobrevir o que ele enuncia no próprio ato de o enunciar é proporcional à autoridade daquele que o enuncia: a fórmula "eu autorizo-vos a partir" só é eo ipso uma autorização se aquele que pronuncia está autorizado a autorizar, tem autoridade para autorizar" [BOURDIEU, 1998, p.116].
} 
manifestações populares. O termo de idealização precisa de uma atenção maior em seu trato. Ora, as artes populares já existiam e já estavam dadas no imaginário e na prática cotidiana do povo nordestino, afinal, se já não existissem, seria impossível recriar uma arte a partir de suas raízes. Foi meio sério e meio de brincadeira que Ariano Suassuna começou a denominar de Armorial toda manifestação artística que fosse de seu agrado. Como que "por brincadeira", Ariano Suassuna transformou o substantivo em adjetivo, atribuindo-lhe caráter qualitativo ao mesmo tempo em que apreciava a sonoridade da palavra. $\mathrm{O}$ uso do nome surge, segundo o escritor, sem grande pensamento sobre os efeitos de sua aplicação, parecendo muito mais como resultado de uma conversa qualquer sobre arte com amigos acompanhada de uma xícara de café em um terraço qualquer. No entanto, tal despretensão pode esconder uma intenção apresentada de modo discreto na própria fala do teatrólogo: Armorial é tudo aquilo que Ariano Suassuna julgava adequado ao seu gosto artístico.

Uma premissa do movimento não pode ser esquecida: "O Movimento Armorial pretende realizar uma Arte brasileira erudita a partir das raízes populares de nossa cultura" (SUASSUNA, 1974, p. 9). Ariano Suassuna rejeitava a ideia do desligamento das raízes populares na nova arte nordestina que queria fundar. Assim, ao ressaltar a arte de Heráldica na nomeação do movimento, não pôde deixar de acentuar o caráter popular da manifestação artística que empresta o nome Armorial. Sobre a presença necessária do popular, Ariano Suassuna ressaltava:

Agora, sempre lembrei a meus amigos que, em nosso País, a Heráldica é uma Arte essencialmente popular, e não aristocrática. A unidade nacional brasileira vem do Povo, e a Heráldica popular brasileira está presente desde os ferros de marcar boi e os "Autos de Guerreiros" do Sertão, até as bandeiras de Cavalhadas e as cores azuis e vermelhas dos pastoris da Zona da Mata. Desde os estan- dartes de Maracatus e caboclinhos do Recife, até as escolas de samba, as camisas e bandeiras dos clubes de Futebol, daqui ou do Rio. (Diário de Pernambuco, Recife, 18 de setembro de 1970, p.32).

O Armorial, na forma que era dada na imaginação criativa do escritor, não podia fugir e negar suas origens nacionais e regionais. A recriação erudita do movimento não poderia relegar a realidade artística brasileira, mas, pelo contrário, era preciso absorver as raízes populares e aprender com elas. Apenas o povo podia fundar uma arte nacional unificada, inclusive na música.

Os primeiros trabalhos dos músicos armoriais datam de 1959, quando o primeiro grupo é formado pelos músicos: Jarbas Maciel, Capiba, Cussy de Almeida e Guerra Peixe. E é desse grupo que surgem as composições iniciais: Galope de Guerra Peixe, uma peça para violino e viola de Capiba e as obras Sem lei nem rei e Cavalo Marinho de Jarbas Maciel (SANTOS, 1999, p. 59). A separação entre os primeiros trabalhos de pesquisa e composição e o lançamento oficial da Orquestra de Câmara Armorial possuem mais de uma década de diferença. É apenas em 1969 que o primeiro Quinteto será formado com base no conjunto popular do Terno, que se dá em um quinteto constituído pelos seguintes instrumentos: dois pífanos, duas rabecas e uma zabumba. A transposição dos instrumentos populares para os eruditos que eram então utilizados pelo primeiro conjunto resulta na seguinte formação: Cussy de Almeida no violino, Jarbas Maciel na viola, José Tavares de Amorim e Rogério Pessoa nas flautas e Henrique Annes no Violão (SUASSUNA, 1974, p. 57). Um ano após a formação do primeiro quinteto o maestro Cussy de Almeida, então diretor do Conservatório de Música de Pernambuco, sugere a junção deste com uma orquestra de cordas que havia fundado (SANTOS, 1999, p. 60). É aí que surge a Orquestra de Câmara Armorial que será responsável pelo concerto de lançamento ofici- 
al do movimento. Um ano após o lançamento, em 1971, o encontro de Ariano Suassuna com o jovem violonista Antônio José Madureira resgatará a ideia inicial do quinteto, muito mais próximo às raízes populares do que uma Orquestra poderia ser.

\section{Popular e Erudito?}

A premissa Armorial baseia-se em recriar uma arte nacional erudita a partir das raízes populares brasileiras. Mas o que define a cultura popular?

Várias são as classificações que designam a categoria cultura popular: as produções feitas para o povo e pelo povo; as feitas para o povo, mas não pelo povo; $e$ as que não são produzidas nem pelo povo nem para o povo, mas por estes adotadas, pois estão adequadas à sua maneira de sentir. (GRILLO, 2015, p. 10).

Podemos compreender como popular toda manifestação artística e/ou cultural que é criada ou aderida pelo povo. Independente da origem, se o coletivo consegue reconhecer-se e adotar tal expressão entre suas formas de representar o mundo, ela se torna, de alguma maneira, uma expressão das mentalidades e das formas de sentir das classes populares.

O ímpeto da criação Armorial se baseia na ideia de que há uma tradição determinada das expressões populares do Nordeste e de que é possível, através disso, buscar a autêntica cultura popular brasileira ${ }^{2}$. O projeto de nacionalização da música e da arte brasileira não é uma ingenuidade estética ou simples desejo artístico. $\mathrm{O}$ ímpeto em trazer a nacionalidade à superfície artística da sociedade brasileira era um projeto tanto político quanto intelectual, e "Além disso, o historiador não pode negligenciar os efeitos da conjuntura histórica que ele está estudando e o papel da música em espaços sociais e tempos históricos determinados" (NAPOLITANO, 2002, p.36). Sendo assim, é preciso percorrer um pouco do trajeto das ideias nacionalistas que permearam a música do Brasil. Segundo Marcos Napolitano, existem três momentos fundamentais na constituição da música popular brasileira e, consequentemente, da constituição da relação estabelecida da música erudita com a sonoridade popular. São eles:

\section{Os anos 20/30 - A consolidação do "samba" como gênero nacional, como mainstream (corrente musical principal) a orientar a organização das possibilida- des de criação e escuta da música popu- lar brasileira.}

Os anos 1959/1968 - A mudança radical do lugar social e do conceito de música popular brasileira que, mesmo incorporando o mainstream, ampliou os materiais e as técnicas musicais interpretativas, além de consolidar a canção como veículo fundamental de projetos culturais e ideológicos mais ambiciosos, dentro de uma perspectiva de engajamento típico de uma cultura política "nacionalpopular".

Os anos 1972-1979 - Periodo histórico pouco estudado, mas fundamental para a reorganização dos termos do diálogo musical presente-passado, tanto no sentido de incorporar tradições que estavam fora do "nacional-popular" (por exemplo, a vertente pop) quanto no de consolidar um amplo conceito de MPB, sigla que define muito mais um complexo cultural do que um gênero musical especifico, dentro da esfera musical popular como um todo (NAPOLITANO, 2002, p.47)

O recorte temporal de interesse para o presente trabalho seria voltado mais precisamente aos anos de 1959, período de formação do primeiro grupo de pesquisa da música armorial (SANTOS, 1999, p.59) e os

\footnotetext{
2“Se, em geral, já é difícil distinguir o que seja, de fato, Arte popular, nas condições particulares do Brasil o problema se agrava mais ainda. Creio, mesmo, que, no campo da Literatura e da Arte brasileiras, existem poucos setores onde reinem maiores confusões do que este da Arte "primitiva" e da Literatura "popular"" [SUASSUNA, 2008, p.151]. "No entanto, essa Arte popular brasileira existe. E não apenas isto: é vigorosa e autêntica, como provam, entre outras manifestações, as xilogravuras populares do Nordeste. E a Literatura popular brasileira também existe, bastando o fato de possuirmos, nos folhetos, o maior e mais variado Romanceiro vivo do mundo, para demonstrar esta minha afirmação" [SUASSUNA, 2008, p.152].
} 
anos de 1970, lançamento oficial do movimento e da Orquestra. Como, no entanto, é "sobretudo entre 1930/60, [que] assistimos ao auge de uma cultura nacional popular, com implicações não só estéticas, mas também ideológicas" (NAPOLITANO, 2002, p.48). Ao mesmo tempo em que apostavam na nacionalização da música, os Armoriais também defendiam que tal nacionalização só poderia ser alcançada a partir dos elementos tradicionais presentes na cultura, que protegeriam nossa arte da influência estrangeira. Quanto ao tradicionalismo armorial:

Tanto os tradicionalistas quanto os modernizadores quiseram construir objetos puros. Os primeiros imaginaram culturas nacionais e populares "autênticas"; procuraram preservá-las da industrialização, da massificação urbana e das influências estrangeiras. Os modernizadores conceberam a arte pela arte, um saber pelo saber, sem fronteiras territoriais e confiaram à experimentação e inovação autônomas suas fantasias de progresso. As diferenças entre esses campos serviram para organizar os bens e instituições. $O$ artesanato ia para as feiras e concursos populares, as obras de arte para os museus e bienais. (CANCLINI, 2000, p. 21).

Segundo Canclini, pensar as manifestações populares como entidades além do tempo, isto é, alheias às mudanças de significações sociais e culturais, como um meio de alcançar uma verdade objetiva sobre aquilo que de fato é autenticamente popular é resultado dos equívocos das visões tradicionalistas e folcloristas. Pois "Do lado popular, é necessário preocupar-se menos com o que se extingue do que com o que se transforma" (CANCLINI, 2000, p. 22).

Parecem equivocados aqueles que pensam a "cultura popular" como "folclore" em seu sentido pejorativo, ou seja, como um conjunto de objetos, práticas e concepções tradicionais, cristalizados no tempo e no espaço. É comum ouvir-se dizer: "o povo não tem cultura" ou " a cultura popular são as nossas tradições”, mas "...é preciso que se pense cultura no plural e no presente e que se parta de uma concepção não normativa e dinâmica", pois a cultura é constitutiva da ação social e, portanto, indissociável dela. (GRILLO, 2015, p. 17).

A dificuldade em definir o que é o popular em uma proposição inequívoca se faz presente até os dias atuais em qualquer empreendimento intelectual que se volte às manifestações do povo. As constantes mudanças às quais essas expressões estão submetidas as tornam praticamente impossíveis de apreendê-las em definitivo. Os sentidos do popular são dados a partir das práticas de ressignificação, do olhar dos intelectuais e estudiosos, das construções midiáticas e dos arranjos sociais lançados sobre essas expressões. O popular é uma construção e não uma essência a priori.

O que é arte não é apenas uma questão estética: é necessário levar em conta como essa questão vai sendo respondida na intersecção do que fazem os jornalistas e os criticos, os historiadores e os museógrafos, os marchands, os colecionadores e os especuladores. Da mesma forma, o popular não se define por uma essência a priori, mas pelas estratégias instáveis, diversas, com que os próprios setores subalternos constroem suas posições, e também pelo modo como os folcloristas e o antropólogo levam à cena a cultura popular para o museu ou para a academia, os sociológicos e os políticos para os partidos, os comunicólogos para a mídia. (CANCLINI, 2000, p. 23).

Se a noção de popular parece fugir de qualquer tentativa de definição, a ideia sobre o que define uma arte erudita pode ser mais claramente delimitada. O primeiro elemento para constituir um campo artístico erudito é a autonomia frente a qualquer instância além da cultura que queira exercer poder de definição sobre ela.

De fato, à medida que se constitui um campo intelectual e artístico (e ao mesmo tempo, oposição de agentes correspondente, seja o intelectual em oposição ao letrado, seja o artista em oposição ao artesão), definindo-se em oposição ao campo econômico, ao campo político e 
ao campo religioso, vale dizer, em relação a todas as instâncias com pretensões a legislar na esfera cultural em nome de um poder ou de uma autoridade que não seja propriamente cultural, as funções que cabem aos diferentes grupos de intelectuais ou de artistas, em função da posição que ocupam no sistema relativamente autônomo das relações de produção intelectual ou artística, tendem cada vez mais a se tornar o princípio unificador e gerador (e portanto, explicativo) dos diferentes sistemas de tomadas de posição culturais e, também, o princípio de sua transformação no curso do tempo (BOURDIEU, 2004, p. 99).

Com a relativa autonomia em relação aos campos extraculturais, os diferentes grupos de artistas e intelectuais podem decidir as próprias regras normativas das diferentes posições ocupadas acerca daquilo que forma a identidade de suas obras. Tal capacidade em reger as próprias regras termina por gerar um princípio unificador de reconhecimento dos diferentes sistemas, ideias e movimentos. É a partir disso que as obras dos artistas armoriais podem ser reconhecidas como constituintes do movimento enquanto tal ao mesmo tempo em que são excluídas todas as outras manifestações que não se adequam as regras predeterminadas, isto é, que não são armoriais. A partir da hierarquia cultural, será armorial aquilo que o mentor do movimento definir como tal. Tal dinâmica social resultará na briga entre o maestro e escritor acerca das discordâncias de como realizar de fato a autêntica música erudita nordestina armorial.

Nesta exclusão daquilo que é exterior ao campo simbólico determinado pelos artistas eruditos, é o próprio grupo constituído que define a qualidade dos trabalhos realizados em seu meio e os artistas aptos a sustentarem tanto o certificado social de qualidade como a autenticidade cultural de seu trabalho e de suas obras.

É justamente isto que ocorre com a qualidade de escritor, de artista ou de erudito, qualidade que parece tão difícil definir porque só existe na e pela relação circular de reconhecimento recíproco entre os artistas, os escritores e os erudi- tos. Todo ato de produção cultural implica na afirmação de sua pretensão à legitimidade cultural. (BOURDIEU, 2004, p. 108).

Delimita-se uma relação mútua entre os artistas que constituem um movimento e podem decidir entre si as normativas que definem os graus de perfeição e autenticidade das obras constituídas no campo erudito. A crítica, por sua vez, adquire o papel vital em traduzir os signos ocultos tornando as obras eruditas, herméticas em suas próprias normativas, mais facilmente inteligíveis além de também legitimar as obras nos âmbitos sociais e culturais.

Destarte, constituem-se "sociedades de admiração mútua”, pequenas seitas fechadas em seu esoterismo e, ao mesmo tempo, surgem os signos de uma nova solidariedade entre o artista e o crítico. [...] E mais, por intermédio de suas interpretações de expert e de suas leituras "inspiradas", tal crítica garante a inteligibilidade das obras fadas, pelas próprias condições em que foram produzidas, a permanecer muito tempo ininteligíveis para aquelas que não estão bastante integrados no campo dos produtores. (BOURDIEU, 2004, p. 107).

\section{A Peleja Armorial}

Em 1969, o primeiro quinteto é formado inspirado no modelo popular do Terno, isto é, conjunto formado por dois pífanos e duas rabecas. É este primeiro quinteto que resultará, no ano seguinte, na Orquestra de Câmara Armorial, ao unir-se com a Orquestra de Cordas dirigida pelo Maestro Cussy de Almeida, então diretor do Conservatório Pernambucano de Música. O Quinteto de 1969 não fazia o uso dos instrumentos populares, desta forma, a transposição para os instrumentos eruditos se dava em: duas flautas, substituindo os pífanos, um violino, substituindo a rabeca, uma viola de Arco, no lugar da viola nordestina, e um conjunto percussivo que buscasse substituir a zabumba. Por sua vez, cada integrante do Quinteto de 1969 assumiu um instru- 
mento distinto: Cussy de Almeida no violino, Jarbas Maciel na viola de arco, José Tavares de Amorim e Rogério Pessoa nas flautas e Henrique Annes, que ocasionalmente assumia um Violão (SANTOS, 1999, p. 59).

Em 1970 a Orquestra de Câmara Armorial é fundada sob a direção do Maestro Cussy de Almeida guiado pelas influências profundas que a formação erudita e a europeia marcaram, como não poderia deixar de ser, na sua educação musical e concepção pessoal dos trabalhos musicais.

A Orquestra Armorial de Câmara de Pernambuco surge, inicialmente, do desejo de Cussy de Almeida criar uma orquestra de cordas com um nivel de execução como as orquestras de câmara europeias. Certamente estava na sua lembrança a excelência da Orquestra de Câmara da Basiléia (Basler Kammerorchester), fundada e dirigida por Paul Sacher, e grupos como I Musici, que ele viu de perto e que teria a formação instrumental mais próxima da que ele usaria na futura orquestra do Conservatório. (BARZA, 2015, p. 30).

Com propensões mais eruditas do que popular, a Orquestra Armorial buscava executar músicas barrocas europeias e brasileiras, fazendo sempre uso dos instrumentos eruditos. Tal postura é dissonante dos ideais arquitetados pelo escritor Ariano Suassuna, que buscava uma arte mais áspera e artesanal, mais semelhante às raízes sertanejas, que só poderiam ser atingidas através do uso direto dos instrumentos populares. É do descontentamento do escritor com a vertente tomada pela Orquestra que surgirá, em 1971, o Quinteto Armorial. É preciso ressaltar, no entanto, que Cussy de Almeida não estava sozinho na sua preferência pelo uso dos instrumentos eruditos utilizados desde o primeiro quinteto, de 1969, que um ano depois formaria a Orquestra.

As primeiras divergências entre a orientação de Suassuna e a preferida pelos músicos que fariam a Orquestra Armorial de Câmera de Pernambuco surgem já nesse primeiro quinteto. Ariano Suassuna sugeria usar instrumentos populares, rabecas, pífanos, percussão, viola sertaneja. Para Jarbas Maciel não havia sentido em fazer uma música nordestina de concerto com instrumentos que sequer poderiam afinar perfeitamente. (BARZA, 2015, p .32).

Foi em 26 de novembro de 1971, na Igreja Rosário dos Pretos, no Recife, que o Quinteto Armorial fez seu concerto de estreia. Assim como a Orquestra, a música do Quinteto era resultado de trabalhos de pesquisa e recriação da arte popular, com uma diferença fundamental: o Quinteto Armorial fazia do uso dos instrumentos populares seu objetivo fundamental, buscando alcançar a sonoridade áspera que Suassuna há tanto tempo sonhava para a música Armorial.

Foi o encontro do mentor do movimento com o violonista Antônio José Madureira que permitiu que Suassuna finalmente pudesse realizar aquilo que desejava há tanto tempo: $\mathrm{O}$ uso dos instrumentos populares na composição armorial.

Fundei, depois, outro Quinteto, que batizei de Quinteto Armorial; é que, entre outubro de 1970 - data do concerto de estreia da Música armorial - e 26 de novembro de 1971, acontecera um fato de maior importância para o nosso Movimento: eu travara conhecimento com Antônio José Madureira, jovem músico que iria abrir novas perspectivas para a Música Armorial... Vi, logo, que estava tratando com uma pessoa de talento fora do comum. E, logo ali, comecei a conversar com ele a respeito dos meus desejos de fundar um novo Quinteto para a Música armorial. Em pouco tempo, estávamos tratando da organização do grupo. Agora, porém, com uma vantagem: Antônio José Madureira dispunha-se a aprender a técnica de viola sertaneja, para incluirmos esse belo instrumento no Quinteto. (SUASSUNA, 1974, p. 59).

Foi assim que surgiu e se constituiu o Quinteto Armorial. Antônio José Madureira assumiu a Viola sertaneja, Edilson Eulálio assumiu o violão, Antônio Carlos Nóbrega de Almeida no Violino, posteriormente 
substituído pela Rabeca, além de dois integrantes do Quinteto de 1969: Jarbas Maciel na viola-de-arco e José Tavares de Amorim na Flauta (SUASSUNA, 1974, p. 52). Em 1973, José Tavares de Amorim foi substituído pelo jovem músico alagoano Egildo Vieira do Nascimento, um exímio tocador de Pífano (SUASSUNA, 1974, p. 54).

Após 4 anos de concretização dos ideais e das obras armoriais, quando a Orquestra e o Quinteto versavam por ideias e abordagens distintas na recriação da arte erudita nordestina, veio à tona na imprensa pernambucana o questionamento das condições financeiras da Orquestra Armorial, lançando o maestro Cussy de Almeida como figura central da problemática e, ao mesmo tempo, evidenciando o sucesso que o Quinteto Armorial gozava naquele momento.

\begin{abstract}
Em agosto de 1974, surgiu uma notícia na imprensa pernambucana que suscitou uma polêmica, por evidenciar que as representações de cultura popular estavam longe de ser homogêneas entre os que se aglutinavam nas propostas artísticas armoriais. Com o título "Fim da Armorial?", o artigo dizia que a Orquestra Armorial parecia estar com os dias contados e apontava Cussy de Almeida como um dos responsáveis pela crise: "Lutando com dificuldade financeira $e$ problemas internos, a Armorial perdeu o excelente violonista chileno Rafael Garcia, Cussy agora tem mil e uma atividades e o mais difícil é reunir a orquestra para uma apresentação. É pouco provável que a Armorial volte a reviver seus mais importantes momentos quando apresentada pela excepcional figura de Ariano Suassuna (...). Infelizmente, tudo isso se perdeu e - ao que se sabe inicialmente - nenhuma gravação foi feita pela Armorial. Enquanto isso, o mestre Ariano partiu modestamente para a formação de um quinteto e, já consagrado, vai perpetuar a arte musical nordestina nas faixas de um long-play. (MORAES, 2000, p. 115).
\end{abstract}

É fato que a Orquestra Armorial só veio a registrar os seus trabalhos em 1975. Tempo relativamente longo se considerarmos o lançamento do Quinteto,
1971, e a gravação de seu primeiro LP, 1974. O artigo, talvez com intuito maior de divulgação do LP do Quinteto, não se refreou em enaltecer a figura de Suassuna e de denegrir, mesmo que indiretamente, o maestro Cussy de Almeida. Em resposta, publicada no dia seguinte no jornal Diário de Pernambuco, o maestro respondeu:

\begin{abstract}
A Armorial graças ao irrestrito apoio dos Governos do Estado e Federal jamais esteve em situação tão privilegiada quanto a atual [...]. O violonista chileno foi substituido por dois uruguaios, um argentino, um gaúcho, um francês e uma sueca. 6x1 portanto. (Diário de Pernambuco, Recife, 21 de agosto e 1974, p.3).
\end{abstract}

Como ressalta Moraes (2000, p. 116), a nota oficial tinha, segundo Almeida, apenas o intuito de tranquilizar o grande público apreciador dos trabalhos da Orquestra, e não de provocar polêmica.

A resposta do Jornal do Commercio, onde originalmente foi publicada a matéria acerca do fim do Armorial, foi publicada em 22 de agosto de 1974, dia seguinte à publicação da nota de esclarecimento do Maestro.

Apesar dessa ressalva feita pela direção da orquestra, a polêmica foi deflagrada. A resposta vinha imperiosa e irônica: "Em deselegante e desarmoniosa Nota Oficial - bastante diferente de suas primeiras suaves notas musicais - a Direção da Orquestra Armorial fez publicar, ontem, no Diário de Pernambuco, matéria paga tentando esclarecer uma indagação aqui publicada, sob o título 'Fim da Armorial? ”. A coluna Dia a Dia (na qual foi publicado o artigo "Fim da Armorial?") Acusou a direção da Orquestra Armorial de confundir quantidade e qualidade, na medida em que mostrava um desinteresse pelo músico nordestino. Em tom irônico, a coluna Dia a Dia atacou: "se os números pesam, preferimos a Banda Furiosa, da cidadezinha de Jaqueiras, que tem 100 músicos: 80 taróis, 19 bombos e uma corneta. (MORAES, 2000, p. 116).

É curioso reparar na mudança de postura por parte do Jornal do Commercio. Na primeira publicação, 
em 20 de agosto de 1974, sobre o título "Fim da Armorial", a indagação se baseava em três argumentos: dificuldades financeiras, falta de tempo do Maestro Cussy de Almeida e, por último, a saída do violonista Chileno Rafael Garcia. Ora, se a saída do violonista chinelo constituía uma problemática tão grande a ponto de aparecer como evidência dos problemas da Orquestra, porque, dois dias depois, a defesa de instrumentistas estrangeiros surge como vetor ao ataque dirigido à Cussy de Almeida? O ano era 1974, a ditadura militar e seus ideais nacionalistas estavam em pleno ápice, e o Jornal era evidentemente submetido à censura dos militares. Entretanto, tal mudança de postura parece mais como objetivo de provocação ao Maestro do que como genuína preocupação.

A polêmica acerca de como constituir e exercer da melhor forma os trabalhos dos músicos armoriais não era nova. Existia de modo empírico desde o lançamento do Quinteto, em 1971, que representava os ideais que Suassuna não via nos trabalhos da Orquestra. Acerca da polêmica, o escritor, defendendo a postura do Jornal do Commercio, comentou:

Julgo muito mais importante a criação, aqui, de um ambiente musical, com nossos próprios meios, do que uma série de concertos dados por virtuoses de fora, que vêm aqui, dão um concerto e vão embora. (Jornal do Commercio, Recife, 23 de agosto de 1974, apud MORAES, 2000, p.117).

Tornava-se pública uma disputa que já vinha se alastrando por anos, mas que, pela possibilidade em separar os trabalhos da música armorial entre a Orquestra e o Quinteto, vinha sendo suavizada. Cussy de Almeida tinha liberdade de reger e dirigir a Orquestra da forma que achasse mais adequada, Ariano Suassuna, em conjunto com Antônio José Madureira, podia exercer o mesmo nos trabalhos do Quinteto. A publicação das pequenas disputas simbólicas na delimitação daqui- lo que seria a melhor representação da arte erudita nordestina acirrou o conflito entre os dois dirigentes dos conjuntos.

\begin{abstract}
Sob o nome de "Orquestras em Guerra", o Jornal do Brasil noticiou: "Recife acompanha tensa a luta surda que vem se desenrolando nos bastidores musicais da cidade, envolvendo, de um lado, o escritor e teatrólogo Ariano Suassuna, e de outro, o maestro e violonista Cussy de Almeida. (MORAES, 2000, p. 124).
\end{abstract}

Músico de extensa formação erudita, tanto brasileira quanto europeia, influenciado e educado diretamente por Villa-Lobos, sorvendo assim os seus ideais, ao maestro Cussy de Almeida a execução de uma verdadeira música erudita nordestina, que por definição era erudita mesmo que se baseasse nas raízes populares, deveria centrar-se no esmero da técnica, da formalidade erudita das estruturas musicais e pela sonoridade dos melhores instrumentos possíveis.

Não adianta querer valorizar-se uma manifestação popular, se não procurarmos usar os nossos conhecimentos eruditos na elaboração de um trabalho de recriação. Do contrário, fiquemos com os artistas populares mesmo. (Jornal do Commercio, Recife, 18 de maio de 1975, apud MORAES, 2000, p.125).

E sobre o uso dos instrumentos populares na orquestração, reconhecendo a dificuldade em adequar estes as estruturas eruditas por suas sonoridades particulares, o maestro ressaltava

A ideia inicial minha, do Suassuna, do Clóvis Pereira, do Guerra Peixe, era a utilização de certos instrumentos mais característicos da cultura popular, como a rabeca, através de instrumentos clássicos da cultura europeia. Até hoje, nenhum luthier conseguiu explicar por que duas rabecas populares, feitas da mesma madeira, nunca têm o mesmo som e a mesma tonalidade, ainda que afinadas exatamente iguais. Isso nos levou a utilizar o violino e a viola para representar as duas rabecas. (Jornal Correio do Po- 
vo, Recife, 17 de março de 1972, apud MORAES, 2000, p.115).

Mas não era esse o ideal que Ariano Suassuna parecia realmente defender na realização da música erudita Armorial. Como vimos, a utilização dos instrumentos populares era tema caro ao escritor, semelhante à defesa já exposta de Mário de Andrade na realização do nacionalismo da música erudita. Mesmo reconhecendo sua incapacidade frente à realidade da execução musical, Suassuna argumentava:

Pessoalmente, eu achava, como ainda acho, que poderia se tirar excelente partido da aspereza do som da rabeca ou do pífano, senão em todas, pelo menos em algumas músicas que tocássemos ou compuséssemos para o Movimento Armorial. Jarbas Maciel (compositor que, com Guerra Peixe, foi indispensável para o surgimento da Música Armorial), muito permeável ao gosto da música asiática, apoiava-me apenas em partes e em certos casos: mas, como músico, achava que, com os instrumentos populares corria-se o risco da desafinação. Eu, porém, talvez por não ser músico, era e sou mais atrevido e julgava que as músicas tocadas por pifano e rabeca - em vez de flauta e violino - adquiriam um caráter primitivo, áspero e forte, muito mais brasileiro. (SUASSUNA, 1974, p. 53).

Não sendo músico, e tendo clara consciência disso, Suassuna não poderia entender os pormenores da execução e teoria musical. A autoridade em tal execução recaía nas figuras consagradas do Maestro Cussy de Almeida e do compositor Jarbas Maciel, ambos discordantes, em diferentes graus, da utilização dos instrumentos populares na música Nordestina. Ariano Suassuna assumia, como já foi exposto anteriormente, que suas direções estéticas em respeito à realização da música armorial eram de cunho muito mais intuitivos do que teóricos. Tanto que foi apenas através de seu aluno, Antônio José Madureira, que conseguiu enfim o apoio, e a habilidade necessária, na realização da execução da música armorial através da aspereza dos instrumentos populares.

Fato é que essas discordâncias foram agravadas pela exposição pública e pelos lugares ocupados por cada um dos dirigentes. É interessante levantar a questão: o escritor aceitaria a direção do maestro em sua escrita, arte que dominava? Não sabemos. Parece, no entanto, que enquanto Cussy de Almeida focalizava seus ideais de execução mais no caráter Erudito do que popular, Suassuna tomava o sentido contrário, guiado, por sua vez, mais pela criatividade e intuição sonora do que pelo domínio conceitual que a realização da música erudita requeria, domínio este que Cussy de Almeida gozava completamente.

Após a resposta de Ariano Suassuna acerca de sua preferência sobre a nacionalidade dos músicos do que os virtuosismos estrangeiros que nada agregam à realidade musical da região, ponto também semelhante à defesa de Mário de Andrade sobre a virtuose estrangeira, o maestro respondeu:

Dias depois, na coluna "Dia a Dia", era editada uma carta de Cussy de Almeida que respondia às ultimas indagações formuladas por essa mesma coluna. Nessa carta, Cussy de Almeida reitera algumas posições de aparente contradição. $\mathrm{Ob}$ servemos, numa de suas respostas, a argumentação: "Quanto à participação de músicos nordestinos na Orquestra Armorial (embora o argumento demonstra um absurdo desconhecimento do que vem a ser o problema da mão-de-obra no gênero no Nordeste), informamos que eles são $55 \%$ do efetivo (isto é, 11 nordestinos para 20 músicos), e esse número não é mais representativo dada à pobreza musical de nossa região". Cussy de Almeida confessou, ainda, que preferia enriquecer o acervo cultural da região utilizando a colaboração internacional e ficando no nivel das tradições pernambucanas a representa-lo com um "folclore subnutrido como vem sendo ultimamente representado". Em resposta a essas ideias, os editores da Dia a Dia agradeciam ao "competente" Cussy de Almeida, mas reafirmavam: "preferimos o nosso subnutrido folclore aos indigestos enlatados importados". (MORAES, 2000, p. 119). 
Pela sua bagagem profissional, depois de ter constituído inúmeras orquestras internacionais e recebido inúmeros prêmios, Cussy de Almeida poderia ter-se sentido prejudicado pelas delimitações que os trabalhos armoriais sofriam. O ataque ao "folclore subnutrido", entretanto, tocava em um ponto muito sensível dos princípios criativos e estéticos dos armoriais. O maestro, em alusão indireta à Suassuna, continuou:

Muita gente importante, de QI bastante alto, também pensa assim, esquecendo que música não se aprende na prática e sim nas bancas escolares, e assim mesmo com muito talento, força de vontade e excelentes mestres. (Jornal do Commercio, Recife, 19 de outubro de 1975, apud MORAES, 2000, p.129).

E volta a atacar Suassuna pela predileção aos instrumentos populares.

Se podemos utilizar uma flauta de prata sofisticada com toda a escala cromática para obter o mesmo resultado de um pífano de taboca, é claro que vamos optar pela primeira. Afinal, ninguém quer andar de carro de boi se se dispõe de uma bela limousine. A menos que por demagogia. (Jornal do Commercio, Recife, 18 de maio de 1975, apud MORAES,2000, p.126).

A escala cromática é uma forma musical que abarca todas as sete notas tonais, Dó, Ré, Mi, Fá, Sol, Lá e Si, como também os acidentes entre estas, conhecidos como sustenidos, meio grau acima, e bemóis, meio grau abaixo. Para um músico profissional do porte de Cussy de Almeida, uma flauta de prata com a escala cromática permite mais opções de trabalho. Seria como se, por analogia, um escritor tivesse seu léxico limitado ou um Pintor tivesse sua paleta de cores reduzidas. Ainda assim, uma flauta de prata nada tem em comum com a sonoridade artesanal da música popular Nordestina e, evidentemente, a acusação de demagogia se dirige diretamente ao escritor Ariano Suassuna.

A partir disto, os ânimos se extremaram a tal pon- to que o líder e idealizador do movimento veio a público excluir a Orquestra do movimento Armorial.

\begin{abstract}
Ariano Suassuna contestou na imprensa pernambucana a legitimidade da denominação de "Armorial" à orquestra dirigida por Cussy de Almeida. Suassuna explicou: "A respeito da questão sobre a qual está havendo essa controvérsia, eu quero explicar, antes de tudo, que uma coisa é o Movimento Armorial e a Música Armorial por um lado; e outra coisa é a Orquestra Armorial. O Movimento Armorial e a Música Armorial surgiram por ideia e sugestão minha. (MORAES, 2000, p. 118).
\end{abstract}

Após o fatídico episódio que buscou deslegitimar os trabalhos da Orquestra dentro daquilo que é denominado Armorial e excluí-la do movimento, pois não correspondia às ideias que Ariano Suassuna havia arquitetado, Cussy de Almeida voltou a defender-se das acusações e ressaltou a importância da Orquestra na constituição e divulgação do Armorial.

Ninguém melhor do que eu valoriza aquilo que é nosso. E aí está a Orquestra Armorial que não me deixa mentir. Foi com ela que a música nordestina ficou conhecida em todo Brasil dentro dos padrões atuais no conceito de Armorial. (Jornal do Commercio, Recife, 18 de maio de 1975, apud MORAES, 2000, p.127).

Após a exclusão da Orquestra do movimento, e talvez buscando preservar o trabalho ao qual se dedicava por tantos anos, Cussy de Almeida tentou registrar a alcunha Armorial para que a Orquestra não pudesse ser deslegitimada por Ariano Suassuna. No entanto, seu pedido foi negado.

Cussy de Almeida lutou pelo nome "Armorial" e, para assegurar a legitimidade na interpretação do que era a defesa dos valores regionais sob o termo "armorial", patenteou este nome na Agência Pernambucana de Marcas, sob a responsabilidade do conservatório Pernambucano de Música. Em setembro de 1975, Cussy de Almeida tentou registrálo no Instituto Nacional de Propriedade Industrial. O pedido foi negado, a partir da argumentação contrária de Ariano 
Suassuna. Segundo a imprensa local, o escritor justificou o pedido de impugnação alegando dois motivos: "primeiro, explicou que o nome "Armorial" é ligado a um movimento cultural e, portanto, não pode ser registrado como se fosse o nome de um produto comercial ou industrial qualquer. Em segundo lugar, sustentou que, se alguém tivesse esse direito, seria ele, por ter criado o Movimento Armorial" (MORAES, 2000, p. 126).

A peleja da música armorial que se instaurou entre o Maestro e o Escritor, respectivamente representados pela Orquestra e pelo Quinteto, evidenciou que a constituição do campo erudito, nas suas regras em comum, nem sempre são pacificas. Cussy de Almeida e Ariano Suassuna não concordavam entre si sobre a melhor maneira de criar a verdadeira arte erudita Nordestina. Enquanto o Maestro buscava apoiar-se mais ao caráter erudito, à técnica, a sua bagagem de músico profissional conceituado voltava-se mais aos parâmetros europeus e aos ideais de seu professor acerca do nacionalismo da música Erudita, Heitor Villa-Lobos. O escritor Ariano Suassuna, por sua vez, mais voltado à imaginação criativa, repudiando a frieza do intelectualismo da academia, voltava-se ao real mágico criativo que tanto via na literatura de Cordel. Queria recriar aquele mundo imagético que tanto permeou sua infância e sua formação como escritor. Em consciência de suas limitações musicais, Suassuna buscava a arte e a criatividade, muito mais amparadas na intuição do que no intelecto. Para o escritor, o Armorial nunca poderia ausentar de suas obras os aspectos artesanais, ásperos e rasgados tão presentes nos timbres dos instrumentos populares dos desafios de cantoria regados ao som das violas, da rabeca e do pífano que constituíam a imagem do Sertão no imaginário do escritor.

\section{Considerações Finais}

A Música Armorial sofria direta influência do movimento regionalista, mas também era moldada pelo nacionalismo folclórico que abarcava toda a música da América Latina do século XX. Sendo constituída por um time de compositores geniais e artistas consagrados como: Jarbas Maciel, Capiba, Guerra Peixe, Cussy de Almeida e Antônio José Madureira, a música Armorial nada devia em sua gigantesca capacidade criativa e domínio da arte de fazer e executar a música erudita nordestina que buscava criar. Os trabalhos dos músicos armoriais influenciaram tão imediatamente o aparecimento de novos conjuntos inspirados pela sua defesa da cultura regional, como o Quinteto Violado, como permanecem até hoje como marca imagética da musicalidade instrumental da região Nordeste. A reconstrução das manifestações populares em estruturas eruditas cumpria o viés de defesa da arte do povo que passava a constituir a identidade nacional nas mais diversas camadas sociais e culturais.

A peleja que se instaurou na discordância de como realizar de fato a música erudita nordestina, polarizada pelas figuras do maestro Cussy de Almeida e pelo escritor e mentor do movimento Ariano Suassuna, demonstrou que a delimitação de um campo erudito não é passiva. Assume a definição das regras internas aquele que detiver o maior capital simbólico dentro do movimento. Dessa forma, toda e qualquer obra do movimento, seguindo a análise de Bourdieu, deveria passar pelo crivo de sua aceitação e condizer com sua imaginação criativa em relação ao Nordeste que se afigurava na arte armorial. Tal postura torna-se evidente no momento em que Suassuna pôde publicamente questionar a identidade Armorial da Orquestra que rompia com aquilo que o escritor sonhava para música do movimento. Esse poder de delimitar as regras e diretrizes, mesmo que pelos critérios de experiência e qualificação devesse pertencer, em relação à música, ao Maestro, ficou de forma evidente sobre o domínio do Escritor. Ariano Suassuna detinha o posto de líder idealizador do movimento. 


\section{Referências}

ALBUQUERQUE JR, Durval Muniz de. A invenção do Nordeste e outras artes. Recife. Ed. Massangana, São Paulo. Cortez Editora, 1999

ALBUQUERQUE JR, Durval Muniz de. Nos destinos de fronteira: história, espaços e identidade regional. Recife, Ed. Bagaço, 2008

BARZA, Sérgio Nilsen. Conservatório Pernambucano de Música - 85 anos: Uma apreciação. Recife. Ed. Cepe, 2015

BOURDIEU, Pierre. A Economia das trocas Simbólicas. $5^{\text {a }}$ Ed. São Paulo: Ed. Perspectiva, 2004. (Trad. Sergio Miceli)

, Pierre. O Poder Simbólico. $2^{\text {a }}$ Ed. Rio de Janeiro: Ed. Bertrand Brasil, 1998. (Trad. Fernando Tomaz)

CANCLINI, Nestor García. Culturas Híbridas. $3^{\text {a }}$ Ed. São Paulo. Ed. USP, 2000 (Trad. Heloísa Pezza Cintrão)

GRILLO, Maria Ângela de Faria. A arte do Povo: Histórias na literatura de Cordel (1900 - 1940). Jundiaí. Ed. Paço Editorial, 2015

MORAES, Maria Thereza Didier de. Emblemas da sagração armorial: Ariano Suassuna e o Movimento Armorial (1970-76). Recife: Ed. Universitária da UFPE, 2000.

NAPOlitAnO, Marcos. História \& Música: História Cultural da Música Popular. São Paulo. Ed. Autêntica, 2002.

SANTOS, Idelette Fonseca do. Em demanda da poética popular: Ariano Suassuna e o movimento Armorial. Campinas, SP: Editora Unicamp, 1999.

SEVERIANO, Jairo. Uma história da música popular brasileira: das origens à modernidade. São Paulo: Ed. 34, 2008

SUASSUNA, Ariano. O Movimento Armorial, $1^{\text {a }}$ Ed. Recife: Ed. Universitária, 1974

, Ariano. Almanaque Armorial/ Ariano Suassuna; seleção, organização e prefácio Carlos Newton Júnior. $2^{\mathrm{a}}$ ed. Rio de Janeiro: Ed. José Olympio, 2008.

, Ariano. Iniciação à estética. 13ª ed. Rio de Janeiro: Ed. José Olympio, 2014

Submissão: 27/04/2017

Aceite: $25 / 03 / 2018$ 